Article

\title{
Application of Full Factorial Design Method for Optimization of Heavy Metal Release from Lead Smelting Slag
}

\author{
Elif Hatice Gürkan ${ }^{1, *}$, Yusuf Tibet ${ }^{2}$ (D) and Semra Çoruh ${ }^{2}$ \\ 1 Department of Chemical Engineering, Ondokuz Mayıs University, Samsun 55139, Turkey \\ 2 Department of Environmental Engineering, Ondokuz Mayis University, Samsun 55139, Turkey; \\ ytibet@hotmail.com (Y.T.); semcoruh@omu.edu.tr (S.Ç.) \\ * Correspondence: elif.gurkan@omu.edu.tr
}

Citation: Gürkan, E.H.; Tibet, Y.; Çoruh, S. Application of Full Factorial Design Method for Optimization of Heavy Metal Release from Lead Smelting Slag. Sustainability 2021, 13, 4890. https://doi.org/10.3390/ su13094890

Academic Editor: Xiaosong Hu

Received: 14 March 2021

Accepted: 20 April 2021

Published: 27 April 2021

Publisher's Note: MDPI stays neutral with regard to jurisdictional claims in published maps and institutional affiliations.

Copyright: (c) 2021 by the authors. Licensee MDPI, Basel, Switzerland. This article is an open access article distributed under the terms and conditions of the Creative Commons Attribution (CC BY) license (https:// creativecommons.org/licenses/by/ $4.0 /)$.

\begin{abstract}
Lead-acid batteries are commonly used as power sources for critical operations in the world. They find application in air-traffic control towers, uninterruptible power supplies (UPS), railroad crossings, military installations, hospitals, and weapons systems. Lead-acid batteries are also known as automotive batteries and industrial batteries. Lead-acid batteries consist of large amounts of lead, sulphuric acid, and plastics. The acid is tremendously irritant and a carrier for soluble information. The lead must control because of a range of adverse health effects. Thus, a collectible system that is easily accessible for waste batteries is needed. In this paper, a sustainable model is proposed for the leaching of lead-acid battery slag. The aim is to optimize the leaching of lead-acid batteries slag with natural materials. The leaching characteristic of the lead smelting slag produced using sepiolite and illite. A $2^{3}$ full factorial design model is used to investigate the combination of the effect of variable factors.
\end{abstract}

Keywords: lead smelting slag; adsorption; immobilization; leaching test; sepiolite; illite

\section{Introduction}

Batteries are used as the most common energy storage equipment. They are the earliest class of rechargeable batteries. Lead storage batteries are known as lead-acid batteries too. They are still used as the most effective energy density solution, being an inexpensive, simple to manufacture technology. Lead-acid batteries find wide application as electronic systems, security systems, energy support systems, storage and support units in renewable energy production, as well as and existing and newly developed different systems.

The essential primary material for lead-acid batteries is sulphuric acid and large amounts of lead. The acid is immensely irritant and is also a suitable carrier for soluble lead metal. Lead is a highly toxic metal that produces health effects in young children, significantly influencing the brain and nervous system development. Exposure to excessive lead levels in the long-term can increase the risk of high blood pressure and kidney damage [1,2].

As well as significant growth for the automotive industry, the rapid increase in other sectors and technologies has strongly driven the use of batteries. Lead-acid batteries are used widely because of their low cost [3-5]. The lead-acid battery has the advantages of high cost performance, large capacity, high power, long life, safety, and reliability. It is currently the world's most significant production and most versatile battery, and it is also the chemical battery with the largest market share and the broadest range of applications. The battery, especially in applications such as starting and large-scale energy storage, is still hard to replace with other new batteries.

Lead-acid batteries have relatively low prices and have comparative advantages such as mature technology, excellent high and low-temperature performance, stability and reliability, high safety, good resource reutilization, and prominent market competitive advantages. Therefore, in the global market, lead-acid batteries occupy a dominant position. 
In recent years, through the continuous technology introduction, digestion, and absorption of the industry and the investment and construction of factories in Turkey by countries such as Europe, the United States, Japan, and South Korea, the manufacturing technology of the leading products of lead-acid batteries in Turkey has approached the advanced international level.

Data show that China's lead-acid battery production accounts for about $45 \%$ of the world's total, followed by the United States, which accounts for about 32\%, Japan ranks third, accounting for nearly 13\%, in addition to Germany, and so on [6]. In Turkey, an estimated 12.5 million batteries were sold in 2018. The old ones were collected with the deposit application [7].

When waste lead-acid batteries are disposed of at random or are stored unlawfully, they can cause the contamination of air, soil, surface water, and groundwater by leaching their toxic components. This waste causes dispersed high lead levels and leadcontaminated sulfuric acid to the environment from deformed and broken batteries [8].

The recovery of waste lead acid batteries is essential for managing lead input to the environment and meeting the market's lead demand in a more energy and cost-effective manner than primary production. As a critical producer of lead acid batteries for the Middle Eastern and Eastern European market, Turkey seems to meet $22-52 \%$ of its total lead demand by waste lead acid battery recovery [9].

Batteries are properly collected from the consumer at the end of their life. Then, they are separated according to various and recycled. The recycling process for the recovery of component materials from lead-acid batteries can be based on physical, chemical, and thermal treatment. The batteries are mechanically crushed to separate the acid and metallic parts. The lead component is smelted and refined from molten slags. The refining process is meant to produce lead of high purity by electrolysis or by precipitation, making a new lead battery (Figure 1) [10,11].

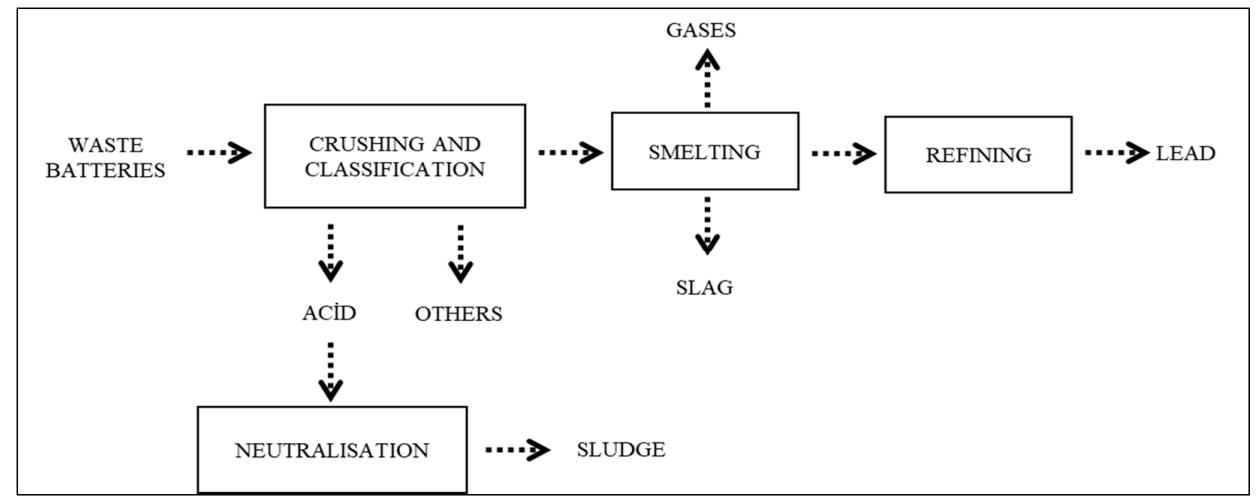

Figure 1. Conventional waste batteries recycling process.

A hierarchy of waste management is the prevention of waste produced at source followed by minimization, reuse, recycling, and energy recovery. Wastes with waste management are converted to conventional and new products [12-14].

Adsorption technology has been used as one of the most practical methods. A sorbent must be eco-friendly, cost effective, industrially viable, and efficient for a wide range of concentrations of different pollutants metals. Owing to their high content of aluminum, iron, magnesium, and calcium, sepiolite and illite have been suggested as cheap natural adsorbents for heavy metal removal. Adsorption characteristics suggested the heterogeneous nature of the adsorbent surface sites concerning the energy of adsorption [15].

In this paper, a sustainable model is proposed for the leaching lead-acid battery slag. The aim is to optimize the leaching of lead-acid batteries slag with natural materials. The leaching characteristic of the lead smelting slag produced using sepiolite and illite. A 23 full factorial design model is used to investigate the combination of the effect of variable factors. The full factorial design, which accounted for all factor interactions, is an 
elaborate approach. The optimization of the leaching behavior has studied the impact of three factors. The variables are the adsorbent type (illite and sepiolite), adsorbent dosage $(10 \%$ and $30 \%)$, and leachate solution (The Toxicity Characteristic Leaching Test (TCLP) and The German Leaching Test (DIN)), levels, namely low and high.

The main and interaction effects have been studied using the Analysis of Variance (ANOVA), an F-test, and the student's t-test. A regression model according to data has been proposed. In the present system's behavior, the most significant factor is the interaction of adsorbent type - leachate solution.

This study's novelty is that full factorial design was applied to optimize process parameters for lead removal from lead smelting slag using natural sepiolite and illite.

The lead smelting slag dumps represent long term sources of metal pollutants, particularly of $\mathrm{Pb}$, to local ground and surface waters. For that reason, this study focuses on the safe disposal and leaching behavior of the lead smelting slag using natural materials. Such research is also important in case of using waste as secondary raw materials for the production of materials placed in the environment [16].

This study's main motivation is to investigate the possibility of sepiolite and illite, which are natural materials that are abundant and inexpensive as an adsorbent for lead removal by using a factorial design.

\section{Materials and Methods}

\subsection{Materials}

Characterization of Chemical Properties of Lead Smelting Slag

Lead smelting slag was obtained from AKUDER, which produces in Istanbul. Standard methods have been used to prepare a leaching solution from industrial waste. The Toxicity Characteristic Leaching Test (TCLP; US EPA Method 1311) (18 h, pH 5.0 buffer HOAc/NaOAc; 20/1; $30 \mathrm{rpm}$ ) and DIN 38414-S4 (24 h; distilled water; 10/1; $30 \mathrm{rpm}$ ) prepared conforms to the standards set by American Chemical Society (ACS Washington, DC, USA) (24 h; distilled water; 10) and are preferred the most commonly. The $\mathrm{pH}$ is measured and a glass fiber filter filters the leaching solution. The leaching solution is used in the experiments [17]. The operation criteria of TCLP and DIN38414-S4 are presented in Table 1.

Table 1. Operation criteria of TCLP and DIN 38414-S4.

\begin{tabular}{ccc}
\hline Operation Criteria & TCLP & DIN38414-S4 \\
\hline Extraction Fluid & Acetic acid solution & Distilled water \\
$\mathrm{pH}$ & $4.93 \pm 0.05$ & - \\
Liquid to solid ratio & $20: 1$ & $10: 1$ \\
Extraction period & $18 \mathrm{~h}$ at $30 \mathrm{rpm}$ & $24 \mathrm{~h}$ at $30 \mathrm{rpm}$ \\
Temperature & Room temperature & Room temperature \\
\hline
\end{tabular}

Natural clays are widely used as adsorbents because of their low cost, abundance, high clay, adsorption, and ion exchange capacity. The adsorption ability of clays is highly dependent on the net negative charge in their structure. Due to this negative charge, clay minerals are gaining the ability to adsorb positively charged species. The adsorption capacity depends on a high surface area and porous structure [18-20].

Sepiolite, also known as a hydrated magnesium silicate, is a soft white natural clay mineral that belongs to a group of layered silicates. The typical chemical formula is $\mathrm{Si}_{12} \mathrm{Mg}_{8} \mathrm{O}_{30}(\mathrm{OH})_{4}\left(\mathrm{OH}_{2}\right)_{4} \cdot 8 \mathrm{H}_{2} \mathrm{O}$. It has various specifications because of the fibrous structure, high surface area, activity, crystal morphology and composition, and porosity. Sepiolite has the highest surface area (BET), about $300 \mathrm{~m}^{2} / \mathrm{g}$, in other clay minerals with a high density of silanol groups $(-\mathrm{SiOH})$. These properties are frequently used in various catalytic, absorbent, and rheological applications [21,22].

Illite contains more potassium than other clay minerals. The chemical formula is $\left(\mathrm{K}, \mathrm{H}_{3} \mathrm{O}\right)(\mathrm{Al}, \mathrm{Mg}, \mathrm{Fe})_{2}(\mathrm{Si}, \mathrm{Al})_{4} \mathrm{O}_{10}\left[(\mathrm{OH})_{2},\left(\mathrm{H}_{2} \mathrm{O}\right)\right]$. Illites are known as micaceous clay minerals. 
The chemical composition of the illite varies depending on the micas that they are formed. Illite, any of a group of mica-type clay minerals widely distributed in marine shales and related sediments. Illite contains more water and less potassium than true micas, but it has a micalike sheet structure and is poorly crystallized [23-25].

The leaching solution is used in the experiments. The natural materials as sepiolite and illite are collected from Eskişehir and Samsun in Turkey.

They are sieved into different fractions. The samples are sheerly washed with deionized water. The chemical composition of leaching smelting slag, sepiolite, and illite is presented in Table 2.

Table 2. The chemical composition (wt. \%) of lead smelting slag, sepiolite, and illite.

\begin{tabular}{cccc}
\hline & Lead Smelting Slag & Sepiolite & Illite \\
\hline $\mathrm{SiO}_{2}$ & 15.41 & 53.47 & 76.90 \\
$\mathrm{Fe}_{2} \mathrm{O}_{3}$ & 40.77 & 0.16 & 1.50 \\
$\mathrm{Al}_{2} \mathrm{O}_{3}$ & 3.01 & 0.19 & 12.00 \\
$\mathrm{TiO}_{2}$ & 0.24 & - & 0.20 \\
$\mathrm{CaO}$ & 2.08 & 0.71 & 0.80 \\
$\mathrm{SO}$ & - & - & - \\
$\mathrm{K}_{2} \mathrm{O}$ & 0.61 & 23.55 & 4.00 \\
$\mathrm{MgO}$ & 0.46 & - & $<0.10$ \\
$\mathrm{Na}_{2} \mathrm{O}$ & 0.42 & - & - \\
$\mathrm{Mn} \mathrm{O}_{3}$ & 5.35 & - & - \\
$\mathrm{PbO} \mathrm{PbS}$ & 0.46 & - & - \\
$\mathrm{LOI}$ & 11.50 & 21.92 & 3.30 \\
$\mathrm{Others}$ & 6.32 & & \\
\hline
\end{tabular}

\subsection{Experimental Procedure}

A study was performed to analyze the effects of leaching and pollutants from lead smelting slag samples. The experiments were confirmed in the reactor containing adsorbent dosage (10\% and 30\%), adsorbent type (sepiolite and illite), and leachate solution (Toxicity Characteristic Leaching Procedure (TCLP) and The German Leaching Test (DIN)).

Firstly, the lead smelting slag was added into leaching solutions (TCLP and DIN), placed in an Erlenmeyer flask under atmospheric pressure and mixed in a magnetic stirrer water bath (Figure 2). At the end of the leaching, the slurry was filtered with a filter and acidified with $\mathrm{HNO}_{3}$ to reduce the $\mathrm{pH}$. The lead concentration in the filtered solution was designed using the atomic absorption spectrophotometer (UNICAM model 929).

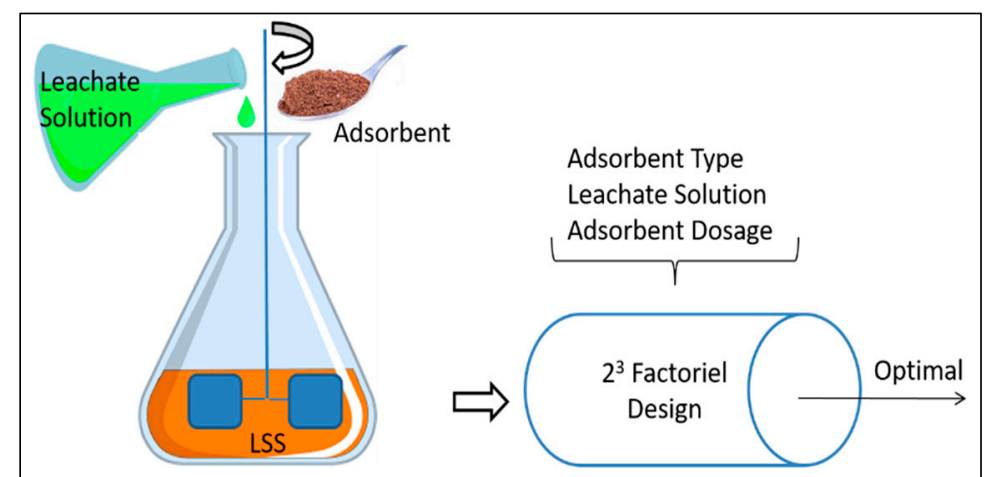

Figure 2. Schematic representation of the experimental studies.

The lead smelting slag was mixed sepiolite and illite (10\% and $30 \%)$ to investigate adsorbents' effects. The samples were added into leaching solutions (TCLP and DIN) placed in an Erlenmeyer flask under atmospheric pressure and mixed in a magnetic stirrer water bath. After the leaching process, the slurry was filtered with a filter and acidified 
with $\mathrm{HNO}_{3}$ to reduce the $\mathrm{pH}$. The filtered solution's metal concentration was determined by using the atomic absorption spectrophotometer (UNICAM model 929).

\subsection{Factorial Design}

The experimental factors such as leachate solution, adsorbent type, and adsorbent dosage were studied in the adsorption process. However, empirical studies are timeconsuming and high-priced. Therefore, to minimize the number of experiments, time, cost of the process studied a factorial design [26-28].

A full factorial design is commonly used to find the relationship between the essential experimental factors' primary and interaction effects [29]. A mathematical model that shows the impact of the experimental factors on the reaction yield is found using this analysis method. This model helps to analyze the main and interaction effects of factors [29-31]. A full factorial design is a widely used experimental design with each factor at two levels (low and high). It takes into investigating the relationship between the levels of factors during the experiment. If $\mathrm{k}$ factors each at two-levels are chosen, the $2^{\mathrm{k}}$ full factorial design is studied. In our work, the present study optimized the adsorption of lead removal from lead smelting slag on sepiolite and illite materials, using a $2^{3}$ full factorial design model. Table 3 illustrated the high and low levels of the experimental factors such as leachate solution, adsorbent type and adsorbent dosage to the $2^{3}$ factorial designs. The levels of the experimental factors were coded as -1 (low) and +1 (high).The low and high levels for the factors were decided according to previous studies. The effects of factors and their interaction on the response have been studied [32-34].

Table 3. The Low and High Levels of experimental factors in the $2^{3}$ full factorial design.

\begin{tabular}{ccc}
\hline Factor & Low Level (-1) & High Level (+1) \\
\hline Adsorbent type (A) & Sepiolite & Illite \\
Leachate solution (B) & DIN & TCLP \\
Adsorbent dosage $(\%)(C)$ & 10 & 30 \\
\hline
\end{tabular}

\section{Results}

A design matrix of three factors has been described. To avoid systematic mistakes, the experiments were conducted randomly.For such a design matrix, the $2^{3}=8$ experiments were required combinations of $\mathrm{A}^{*} \mathrm{~B}-{ }^{*} \mathrm{C}$ The experimental design matrix in coded variables and the results were illustrated in Table 4 . The signs in the interaction columns are the signs that result when multiplying the main effect columns in the interaction of interest. A factor effect is that the average response depends on the high level at the factor's low level. Using Equation (1), calculate the main effect of a factor's high and low levels [35]. Informal analysis using the main effects plot can be powerful.

$$
E_{i}=\frac{1}{2^{k-1}} \sum_{j=1}^{2^{k}} c_{i, j} Y_{j}
$$

where $k$ is the number of factors, $i$ is the which effect you are calculating, $j$ is the number of runs you are considering and $c$ is the coded value. 
Table 4. Design matrix in coded and the experimental responses.

\begin{tabular}{|c|c|c|c|c|c|}
\hline \multirow{2}{*}{ Experiment } & \multirow{2}{*}{ A } & \multirow{2}{*}{ B } & \multirow{2}{*}{$\mathrm{C}$} & \multicolumn{2}{|c|}{ Removal Efficiency (\%) } \\
\hline & & & & Trial 1 & Trial 2 \\
\hline 1 & -1 & -1 & -1 & 40.80 & 42.56 \\
\hline 2 & 1 & -1 & -1 & 0.14 & 0.20 \\
\hline 3 & -1 & 1 & -1 & 8.03 & 10.01 \\
\hline 4 & 1 & 1 & -1 & 9.41 & 7.45 \\
\hline 5 & -1 & -1 & 1 & 94.71 & 96.36 \\
\hline 6 & 1 & -1 & 1 & 11.85 & 8.45 \\
\hline 7 & -1 & 1 & 1 & 17.58 & 19.82 \\
\hline 8 & 1 & 1 & 1 & 18.01 & 22.21 \\
\hline
\end{tabular}

A linear mathematical model is created in the full factorial design to illustrate the influence and interaction between the measured response parameters $(Y)$ [36]. The mathematical model showing the relationships between experimental data is described in the regression model and obtained from Equation (2) [32].

$$
Y=\beta_{0}+\beta_{1} A+\beta_{2} B+\beta_{3} C+\beta_{12} A B+\beta_{13} A C+\beta_{23} B C+\beta_{123} A B C
$$

where $\mathrm{Y}$ is the predicted reaction efficiency. The constant term is $\beta_{0}$. The respective effect coefficient is $\beta$ and $A, B, C$, stands for adsorbent type, leachate solution, and adsorbent dosage, respectively. $Y=f(X)$ equation for removing lead is given in Equation (3).

$$
\mathrm{Y}=25.474-15.759 \mathrm{~A}-11.409 \mathrm{~B}+10.649 \mathrm{C}+15.96 \mathrm{AB}-5.234 \mathrm{AC}-5.309 \mathrm{BC}+5.734 \mathrm{AB}
$$

The Student's $t$-test has calculated the regression model's coefficients to analyze their influence on the reaction efficiency [37]. The regression coefficients, the effects, $t$-values and $p$-values are shown in Table 5.

\begin{tabular}{|c|c|c|c|c|c|}
\hline Term & Effect & Coef & SE Coef & $\mathrm{T}$ & $\mathbf{P}$ \\
\hline Constant & & 25.474 & 0.432 & 58.95 & 0.000 \\
\hline $\begin{array}{l}\text { Adsorbent } \\
\text { Type }\end{array}$ & -31.519 & -15.759 & 0.432 & -36.47 & 0.000 \\
\hline $\begin{array}{l}\text { Leachate } \\
\text { solution }\end{array}$ & -22.819 & -11.409 & 0.432 & -26.40 & 0.000 \\
\hline $\begin{array}{l}\text { Adsorbent } \\
\text { Dosage } \\
\text { Adsorbent }\end{array}$ & 21.299 & 10.649 & 0.432 & 24.64 & 0.000 \\
\hline $\begin{array}{l}\text { Type Leachate } \\
\text { Solution } \\
\text { Adsorbent }\end{array}$ & 31.929 & 15.964 & 0.432 & 36.94 & 0.000 \\
\hline $\begin{array}{l}\text { Type*Adsorbent } \\
\text { Dosage }\end{array}$ & -10.469 & -5.234 & 0.432 & -12.11 & 0.000 \\
\hline $\begin{array}{l}\text { Leachate } \\
\text { solu- } \\
\text { tion*Adsorbent } \\
\text { Dosage }\end{array}$ & -10.619 & -5.309 & 0.432 & -12.29 & 0.000 \\
\hline $\begin{array}{l}\text { Adsorbent } \\
\text { Type*Leachate } \\
\text { solu- } \\
\text { tion*Adsorbent } \\
\text { Dosage }\end{array}$ & 11.469 & 5.734 & 0.432 & 13.27 & 0.000 \\
\hline
\end{tabular}

Table 5. Estimated Effects and Coefficients for Lead Release. 
In the statistical analysis of experimental data, it is essential to assume that the data is in the normal distribution. When the data distribution is normal, the normal probability plot shows that points fall reasonably close to a straight line. The normality of the data can be surveyed by plotting the normal probability plot of the residuals.

The residuals are the difference between the observed and the fitted from the regression. Figure $3 a$ is the normal probability plot. Figure $3 b$ plots the residuals versus the fitted values, and it could be seen that the experimental points are reasonably aligned, suggesting normal distribution. Figure $3 \mathrm{~d}$ is a plot of the residuals versus the observation orders. The residuals appear to be randomly scattered about zero.

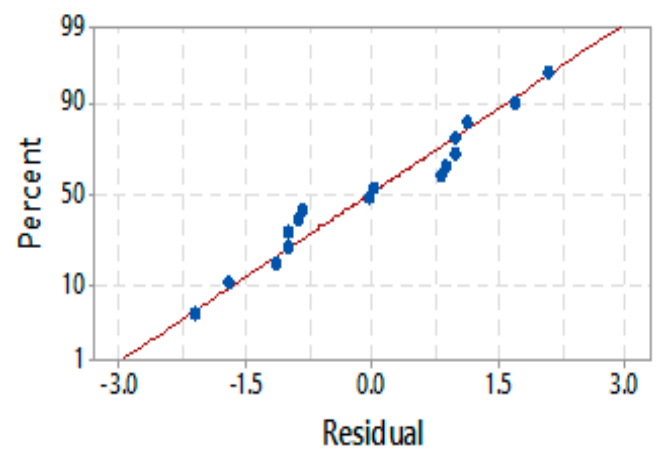

(a)

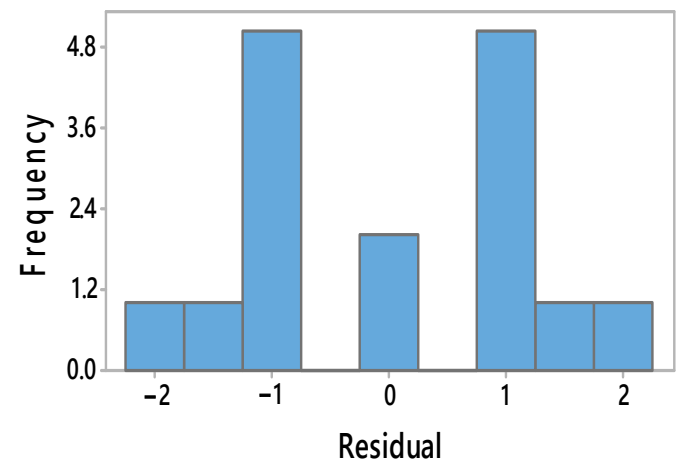

(c)

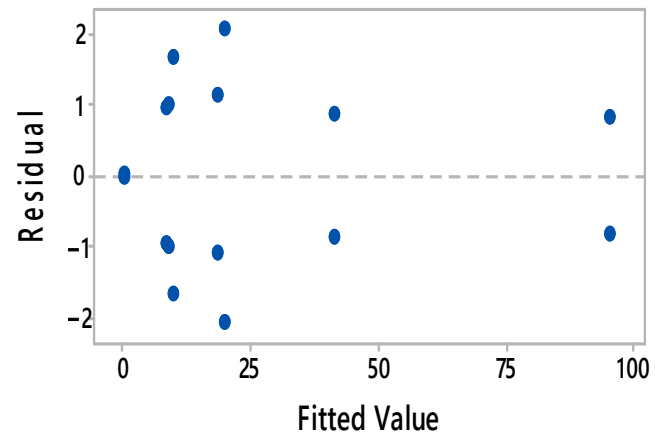

(b)

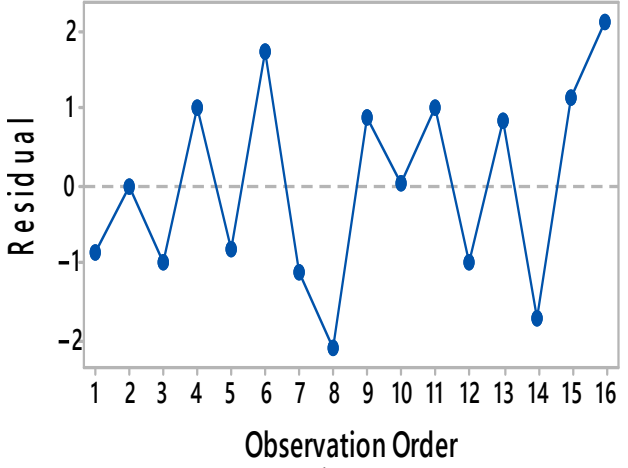

(d)

Figure 3. (a) Normal Probability Plot (b) Versus Fits (c) Histogram (d) Versus Order for Removal Efficiency.

The main effects of low and high levels of adsorbent type, leachate solution, and adsorbent dosage are shown in Figure 4. From Figure 4, we can see a change from low to high levels of experimental factors. This indicates that the high level of adsorbent type and leachate solution negatively affects the adsorbent dosage positively impacting the reaction efficiency.

These results indicate that leaching of lead metal ions decreased as the level of sepiolite and illite increased. Moreover, these results show that in general, sepiolite is more effective than illite. The enhancement of lead removal with increasing adsorbent dosage can be attributed to the fact that increasing the amount of adsorbent provides more binding sites (increased surface area) for the adsorption of lead ions onto the sepiolite and illite, leading to an increase in the interaction between adsorbent and lead ions. On the surface of the sepiolite the oxidized functional groups are present as $\mathrm{SiO}_{2}, \mathrm{MgO}$ and $\mathrm{Al}_{2} \mathrm{O}_{3}$. The surface of silica has a high affinity towards lead ions. This behavior may be explained based on the higher number of available sorbent sites for lead ions binding [38,39]. 


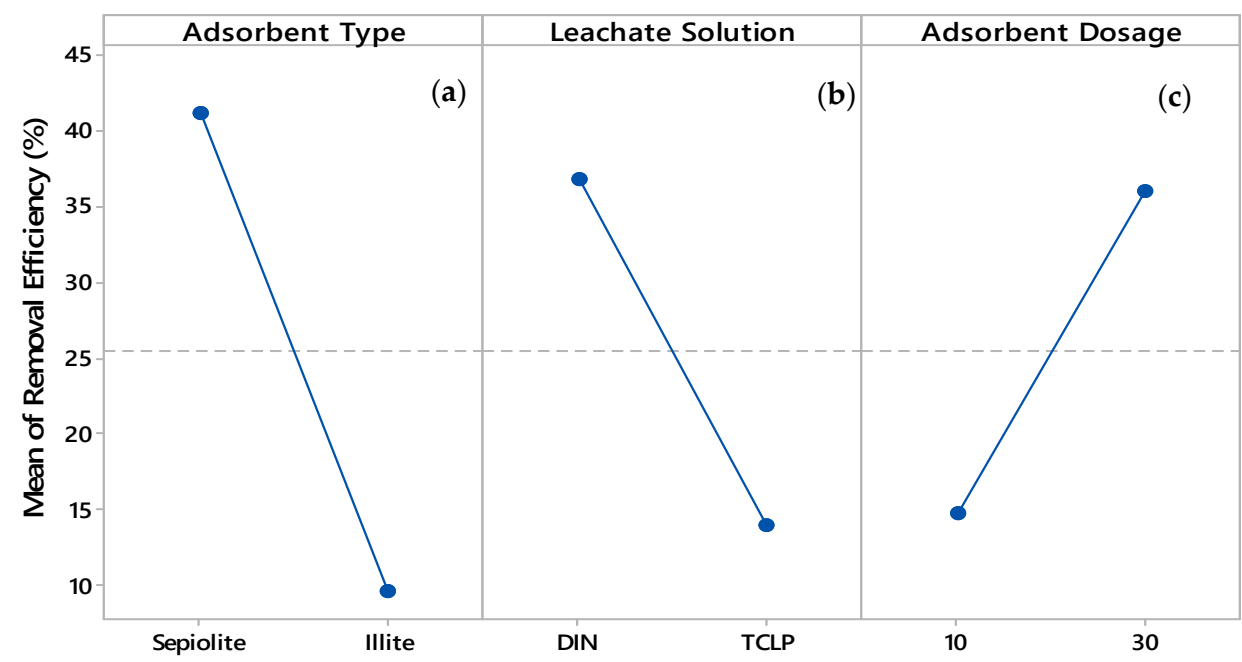

Figure 4. Main effects plot for reaction yield R (\%): (a) adsorbent type, (b) leachate solution and, (c) adsorbent dosage.

When the main effect is the effect of one of the independent factors on the dependent factor, an interaction effect is an influential experimental factor that differs depending on the second experimental factor. An interaction among two factors can be explained as the effect of a factor on the response depending on the other factor [31,40-47].

In Figure 5, the lines on the graphs are not parallel. In these cases, there is interaction, and we can decide on its significance from the two factors ANOVA.

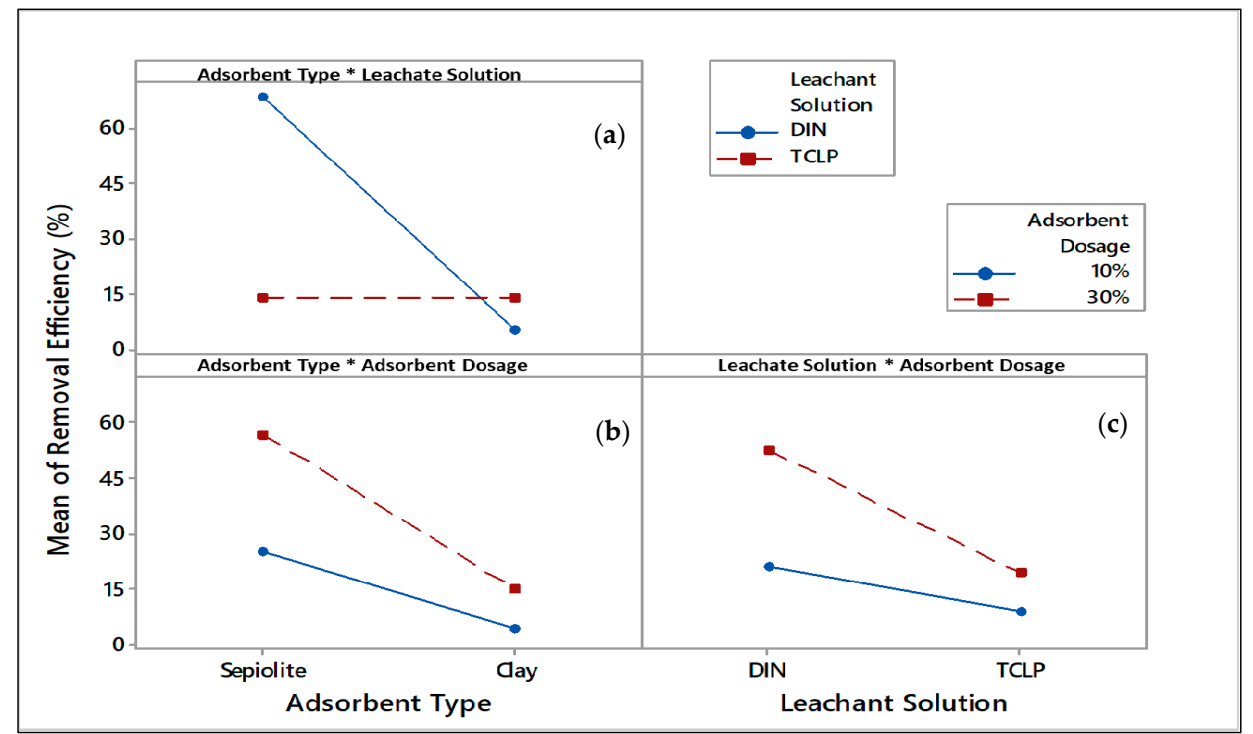

Figure 5. Interaction effects plot: (a) adsorbent type*leachate solution, (b) adsorbenttype*adsorbent dosage and (c) leachate solution*adsorbent dosage.

The interaction plot for lead removal efficiency shows the significant interactions between the adsorbent type and the adsorbent dosage and between the leachate solution and the adsorbent dosage. However, the interaction between the adsorbent type and the leachate solution is the most vital.

Student's t-test was employed to find the relative importance of individual parameters and their interaction and the results are illustrated in Pareto chart. A Pareto chart is concluded which of these variables and interactions are most significant. Pareto charts (Figure 6) are illustrated which variables have the most effective cumulative effect on the results. Figure 6 shows the Pareto chart of standardized effects at ( $p$-value) $p=0.05$. 
The values of main effects and interaction effects are higher than 2.31. The main effects $A, B$, $\mathrm{C}$, and the interactions $\mathrm{AB}, \mathrm{AC}, \mathrm{BC}$, and $\mathrm{ABC}$ that exceed the reference line are significant, according to Figure 6.

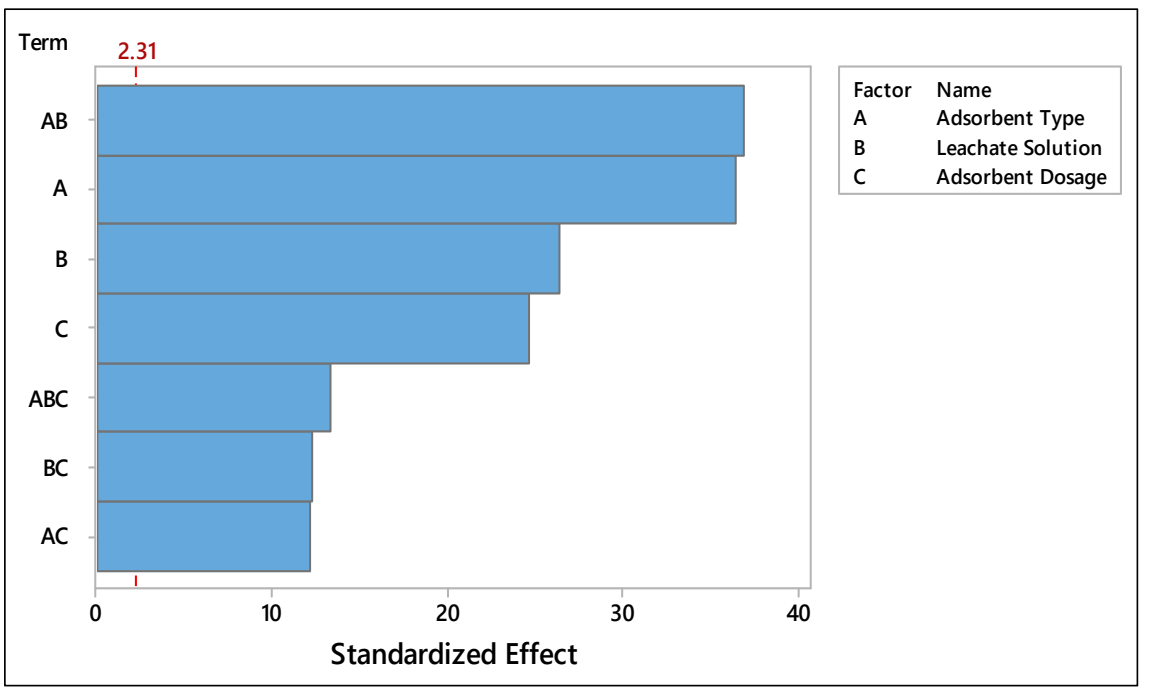

Figure 6. Pareto chart for lead removal.

The normal probability plot is used to see individual data items that don't fit a normal distribution. If a plotted effect doesn't provide this line, this effect is thought to be "significant". According to Figure 7, the main effects A,B,C, and the interactions A, B, $A C, B C$, and $A B C$ are significant statistically. Since A, B, AC and BC lie on the left-hand side, the line hurts the model. The interaction of adsorbent type (A) appears to have an enormous effect because it lies furthest from the line.

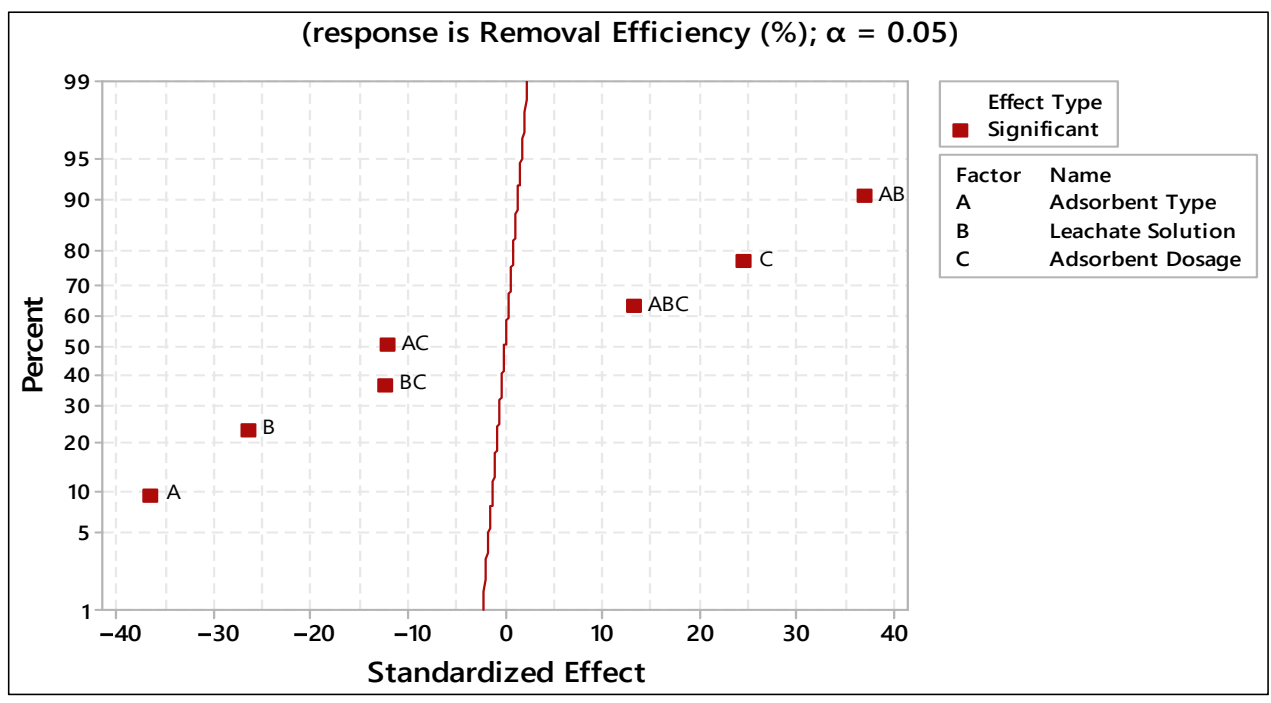

Figure 7. Normal probability plot of standardized effects.

A multi-vari chart is a graphical representation of the relationships between factors and response. Use a multi-vari chart to present variance data analysis in a graphic form, especially in the preliminary stages of data analysis to view data, possible relationships, and root causes for variation. Figure 8 shows the low level of adsorbent type (sepiolite) performs better than the high level of adsorbent type (illite). Figure 8 shows that the DIN method is more effective on the results than the TCLP method. Moreover, there is evidence that the effect of dosage is more pronounced in sepiolite with DIN. 


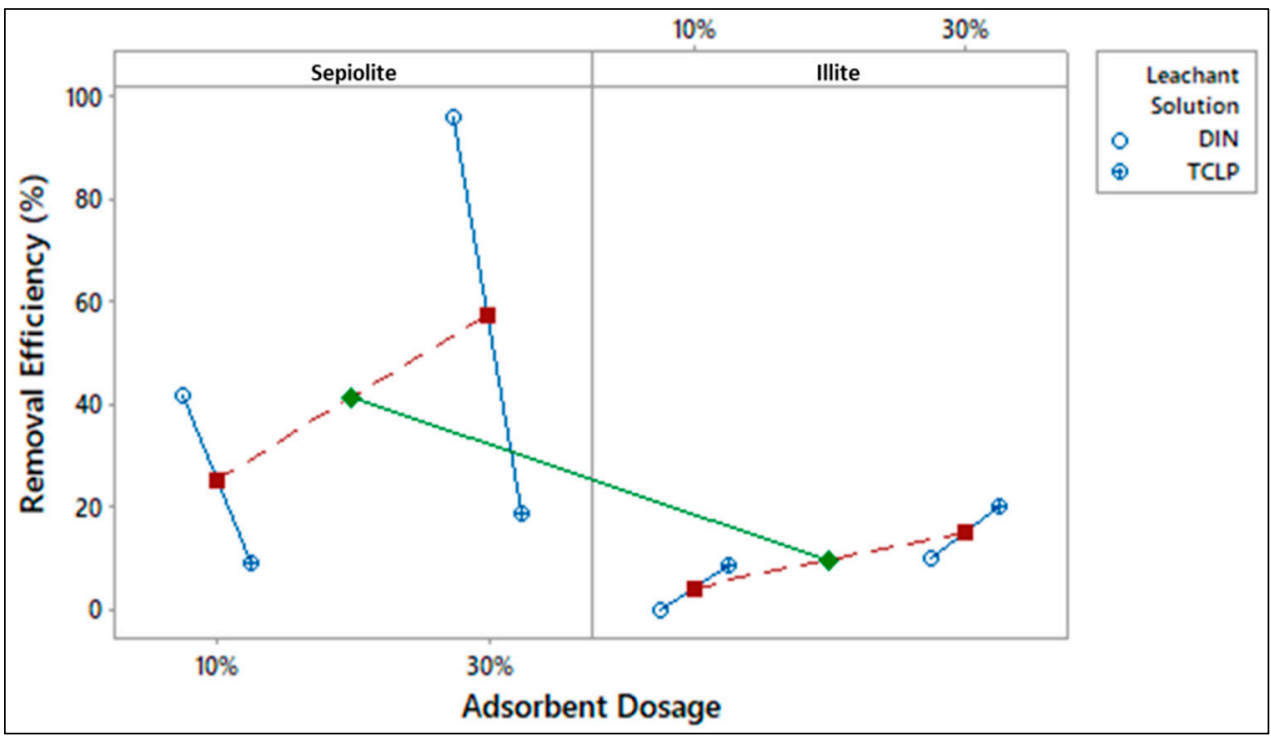

Figure 8. Multi-Vari Chart plot for lead removal efficiency of lead smelting slag.

The removal of lead as a function of the adsorbent type and leachate solution is given in Figure 9a. Figure 9a shows that the lead removal decreased with changing the adsorbent type from sepiolite to illite and changing the leachate solution from DIN to TCLP. This means that sepiolite may be employed as an ion-exchanger to remove lead due to its cation-exchange capacity [38]. The TCLP provided more acidic conditions for the lead smelting slag than the DIN [48].
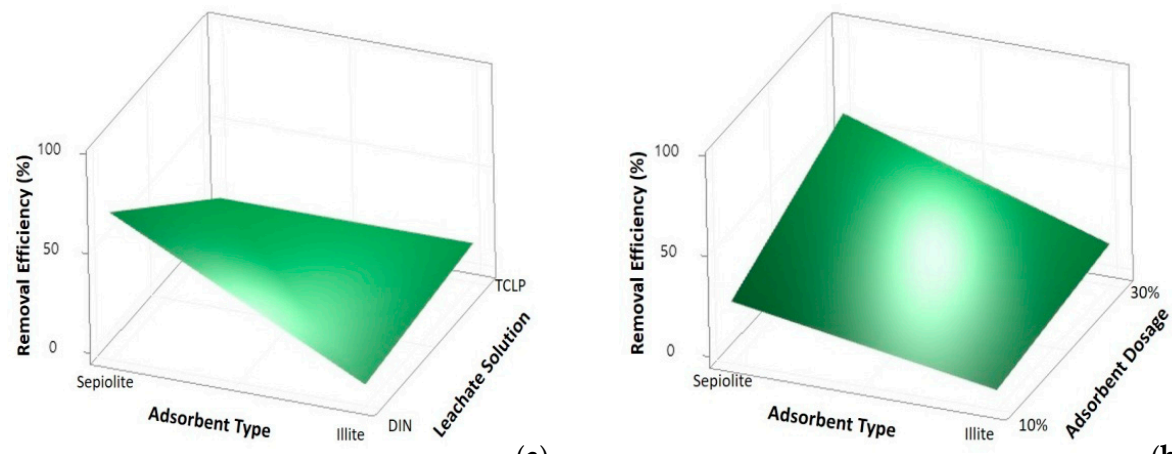

(a)

(b)

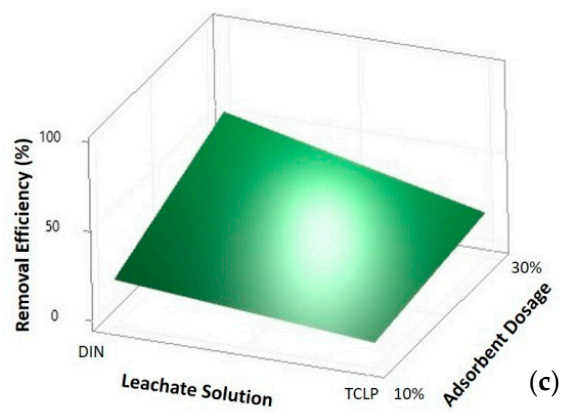

Figure 9. Response surface for lead removal interaction effects plot (a) adsorbent type*leachate solution, (b) adsorbent type*adsorbent dosage and (c) leachate solution*adsorbent dosage.

The removal of lead as a function of the adsorbent type and the adsorbent dosage is given in Figure 9b. It shows that the lead removal increased with the adsorbent dosage from $10 \%$ to $30 \%$. This is because increasing the adsorbent dosage can be attributed to the increased surface area and adsorption sites of the adsorbent [49]. 
The removal of lead as a function of the leachate solution and the adsorbent dosage is given in Figure 9c. This implies that DIN is effective in the adsorption of lead as the dosage increased till a dosage of about $30 \%$.

\section{Conclusions}

The poor management of solid waste collection and disposal may lead to leachate pollution of surface water or groundwater. Lead-acid battery waste can discharge acid into waterways and soil, posing a threat to human health. The waste lead storage battery is the most important recyclable lead material. Because lead is toxic to the soil, water and humans, the recycling and management of waste lead-acid batteries has become a significant challenge and is capturing much public attention.

In this work, experimental tests of the leaching of lead-acid batteries of lead were reported. This study aimed to investigate the adsorption of lead removal from lead smelting slag on sepiolite and illite materials. A full factorial design creates experimental points using all the possible combinations of the levels of the factors in each complete trial or replication of the experiments. For this purpose, a $2^{3}$ full factorial design (three factors, at two levels) was employed to evaluate the importance and interactions of adsorbent type, leachate solution, and adsorbent dosage.

Based on these results, sepiolite is a more effective adsorbent than illite. The illite has a negative effect for lead removal. When the effect of the factors is negative, removal efficiency decreases as the factors are changed from low to high levels (as seen from adsorbent type and leachate solution). The highest removal efficiency was about $93.65 \%$ at adsorbent type (A); sepiolite, leachate solution(B); DIN, and adsorbent dosage $30 \mathrm{~g} / \mathrm{L}$ batch conditions. The lowest removal efficiency was found as about $0.14 \%$ at adsorbent type (A); illite, leachate solution(B); DIN, and adsorbent dosage $10 \mathrm{~g} / \mathrm{L}$, for batch conditions [50]. The experimental design results also indicated that the leachate solution and adsorbent type are essential in lead removal.

TCLP and DIN were applied and leachate was obtained for lead smelting slag. Metal concentrations in the TCLP leachate were significantly higher than the metal concentrations in the DIN leachate. This is due to the $\mathrm{pH}$ difference between the applied extraction fluids and the final leachate $\mathrm{pHs}$. The $\mathrm{pH}$ of the TCLP extraction fluid was around $4.93 \pm 0.05$. Therefore, the TCLP provided more acidic conditions for the lead smelting slag than the DIN [48].

The results of the present study suggest that sepiolite effective adsorbents for the lead released from slag. The results obtained in this study are significant in evaluating the contribution to the literature.

Author Contributions: Methodology, E.H.G. and Y.T.; investigation, E.H.G.; resources, Y.T.; writing-review and editing, E.H.G.; supervision, S.Ç. All authors have read and agreed to the published version of the manuscript.

Funding: This research received no external funding.

Institutional Review Board Statement: Not applicable.

Informed Consent Statement: Not applicable.

Data Availability Statement: Not applicable.

Conflicts of Interest: The authors declare no conflict of interest.

\section{References}

1. Wani, A.A.; Usmani, J.A. Lead toxicity: A review. Interdiscip. Toxicol. 2015, 8, 55-64. [CrossRef]

2. Gorini, F.; Muratori, F.; Morales, M.A. The Role of Heavy Metal Pollution in Neurobehavioral Disorders: A Focus on Autism. Rev. J. Autism Dev. Disord. 2014, 1, 354-372. [CrossRef]

3. May, G.J.; Davidson, A.; Monahov, B. Lead batteries for utility energy storage: A review. J. Energy Storage 2018, 158, 145-157. [CrossRef] 
4. Pillot, C. The recharge able battery market and main trends. In Proceedings of the 15th European Lead Battery Conference, Valletta, Malta, 13-16 September 2016; pp. 2014-2025.

5. Kurt, O. Interviewer; Mutlu Akü ve Malzemeleri San. A.Ş.: Tuzla, İstanbul, 2012.

6. Jiang, W.Y. Global and Chinese Lead-Acid Battery Industry Report. Forward-Industrial Research Institute. Available online: https:/ / www.qianzhan.com/analyst/detail/220/181101-627d5bc4.html (accessed on 30 March 2021).

7. TÜIK-VeriPortall. Available online: https://data.tuik.gov.tr/Kategori/GetKategori?p=sanayi-114\&dil=1 (accessed on 31 March 2021).

8. Milton, B.A.; Juan, V.Z.; Maria, M.V.; Alejandro, A.; Juan Jose, P.C. Chemical characterization and local dispersion of slag generated by a lead recovery plant in Central Mexico. Afr. J. Biotechnol. 2014, 19, 1973-1976.

9. Çelebi, S.; Yetiş, Ü.; Ünlü, K. Identification of management strategies and generation factors for spent lead acid battery recovery plant wastes in Turkey. Waste Manag. Res. J. Sustain. Circ. Econ. 2019, 37, 199-209. [CrossRef]

10. U.S. Environmental Protection Agency (EPA). Water: Monitoring \& Assessment-5.9 Conductivity; U.S. Environmental Protection Agency (EPA): Washington, DC, USA, 2012.

11. Ballantyne, A.D.; Hallett, J.P.; Riley, J.; Shah, N.; Payne, D.J. Lead acid battery recycling for the twenty-first century. R. Soc. Open Sci. 2018, 5, 171368. [CrossRef]

12. Boxall, N.J.; Adamekab, N.; Chengac, K.Y.; Haqued, N.; Bruckardd, W.; Kaksonen, A.H. Multi stage leaching of metals from spent lithiumi on battery waste using electrochemically generated acidic lixiviant. Waste Manag. 2018, 74, 435-445. [CrossRef] [PubMed]

13. Marotz, C.A.; Sanders, J.G.; Zuniga, C.; Zaramela, L.S.; Knight, R.; Zengler, K. Improving Saliva Shotgun Metagenomics By Chemical Host Dna Depletion. Microbiome 2018, 6, 42. [CrossRef]

14. Jaria, G.; Silva, C.P.; Ferreira, C.I.A.; Otero, M. Sludge from paper mill effluent treatment as raw material to produce carbon adsorbents: An alternative waste management strategy. J. Environ. Manag. 2017, 188, 203-211. [CrossRef]

15. Malakootian, M.; Hossaini, H.; Asadipour, A.; Daneshkhah, M. Preparation and characterization of modified sepiolite for the removal of Acid green 20 from aqueous solutions: Isotherm, kinetic and process optimization. Appl. Water Sci. $2018,8,174$. [CrossRef]

16. Li, S.; Huang, X.; Muhammad, F.; Yu, L.; Xia, M.; Zhao, J.; Jiao, B.; Shiau, Y.C.; Li, D. Waste solidification/stabilization of lead zinc slag by utilizing fly ash based geopolymers. Econ. Environ. Stud. 2016, 16, 819-830. [CrossRef]

17. Townsend, T.; Jang, Y.C.; Tolaymat, T.; Jambeck, J.A. Final Report on Leaching Tests for Evaluating Risk in Solid Waste Management Decision Making; Department of Environmental Engineering Sciences, University of Florida: Gainesville, FL, USA, 2003.

18. Uddin, M.K. A review on the adsorption of heavy metals by clay minerals, with special focus on the past decade. Chem. Eng. J. 2017, 308, 438-462. [CrossRef]

19. Yuan, G.; Theng, B.K.G.; Churchman, J.; Gates, W.P. Clay sand Clay Minerals for Pollution Control. Dev. Clay Sci. 2006, 1, 625-675.

20. Srinivasan, R. Advances in Application of Natural Clayand Its Composites in Removal of Biological, Organic, and Inorganic Contaminants from Drinking Water. Adv. Mater. Sci. Eng. 2011, 2011, 1687-843417. [CrossRef]

21. Nohales, A.; Solar, L.; Porcar, I.; Vallo, C.I.; Go'mez, C.M. Morphology, flexural, and thermal properties of sepiolite modified epoxy resins with different curing agents. Eur. Polym. J. 2006, 42, 3093-3101. [CrossRef]

22. Liu, H.; Chen, W. Magnetic mesoporous imprinted adsorbent based on $\mathrm{Fe}_{3} \mathrm{O}_{4}$-modified sepiolite for organic micro pollutant removal from aqueous solution. R. Soc. Chem. 2015, 5, 27034-27042.

23. Bauer, A.; Velde, B.; Gaupp, R. Experimental constraints on illite crystal morphology. Clay Miner. 2000, 35, 587-597. [CrossRef]

24. Day-Stirrat, R.J.; Aplin, A.C.; Kurtev, K.D. Latedia genesis of illite-smectite in the Podhale Basin, southern Poland: Chemistry, morphology, and preferred orientation. Geosphere 2017, 13, 2137-2153. [CrossRef]

25. Yin, J.; Deng, C.; Yu, Z.; Wang, X.; Xu, G. Effective Removal of Lead Ions from Aqueous Solution Using NanoIllite/Smectite Clay: Isotherm, Kinetic, and Thermodynamic. Model. Adsorpt. Water 2018, 10, 210. [CrossRef]

26. Elhalil, A.; Tounsadi, H.; Elmoubarki, R.; Mahjoubi, F.Z.; Farnane, M.; Sadiq, M.; Abdennouri, M.; Qourzal, S.; Barka, N. Factorial experimental design for the optimization of catalytic degradation of malachite green dye in aqueous solution by Fenton process. Water Resour. Ind. 2016, 15, 41-48. [CrossRef]

27. Brasil, J.L.; Martins, L.C.; Ev, R.R.; Dupont, J.; Dias, S.L.P.; Sales, J.A.A.; Airoldi, C.; Lima, E.C. Factorial design for optimization of flow injection pre concentration procedure for copper(II) determination in natural waters, using 2-aminomethylpyridine grafted silica gel as adsorbent and spectrophotometric detection. Int. J. Environ. Anal. Chem. 2005, 15, 475-491. [CrossRef]

28. Montgomery, D.C. Design and Analysis of Experiments, to Design, Data Analysis and Model Building; John Wiley and Sons: New York, NY, USA, 1997.

29. Zhao, Y.; Gu, W.; Li, Y. Molecular design of 1,3,5,7-tetracn derivatives with reduced bioconcentration using 3D-QSAR modeling, full factorial design, and molecular docking. J. Mol. Graph. Model. 2018, 84, 197-214. [CrossRef]

30. Bounouri, Y.; Berkani, M.; Zamouche, A.; Ycerz, L. Optimization and modeling of synthesis parameters of neodymium(III) bromide by dry method using full factorial design analysis. Arab. J. Chem. 2020, 13, 366-376. [CrossRef]

31. Barka, N.; Abdennouri, M.; Boussaoud, A.; Galadi, A.; Baâlala, M.; Bensitel, M.; Sahibed-Dine, A.; Nohair, K.; Sadiq, M. Full factorial experimental design applied to oxalicacid photo catalytic degradation in $\mathrm{TiO}_{2}$ aqueous suspension. Arab. J. Chem. 2014, 7, 752-757. [CrossRef] 
32. Torrades, F.; García-Montaño, J. Using central composite experimental design to optimize the degradation of realdye waste water by Fenton and photo-Fenton reactions. Dyes Pigment 2014, 100, 184-189. [CrossRef]

33. Montgomery, D.C. Design and Analysis of Experiments, 8th ed.; John Wiley \& Sons: New York, NY, USA, 2012.

34. Mendonça, D.R.; Andrade, H.M.C.; Guimarães, P.R.B.; Vianna, R.F.; Meneghetti, S.M.P.; Pontes, L.A.M.; Teixeira, L.S.G. Application of full factorial design and Doehlert matrix for the optimisation of beef tallow methanolysis via homogeneous catalysis. Fuel Process. Technol. 2011, 92, 342-348. [CrossRef]

35. Gygi, C.; Decarlo, N.; Williams, B. Six Sigma for Dummies; International Lead and Zinc Study Group. Annual Lead and Zinc Statistics Report; Wiley Publishing Inc.: Indianapolis, IN, USA, 2005.

36. Ismail, A.A.; El-Midany, A.A.; Ibrahim, I.A.; Matsunaga, H. Heavy metal removal using $\mathrm{SiO}_{2}-\mathrm{TiO}_{2}$ binary oxide: Experimental design approach. Adsorption 2008, 14, 21-29. [CrossRef]

37. Budka, A.; Łacka, A.; Gaj, R.; Jajor, E.; Korbas, M. Predicting winter wheat yields by comparing regression equations. Crop Prot. 2015, 78, 84-91. [CrossRef]

38. Padilla, E.; Ramos, R.L.; Barron, J.M.; Leyva, R. Adsorption of Heavy Metal Ions from Aqueous Solution onto Sepiolite. Adsorpt. Sci. Technol. 2011, 29, 569-584. [CrossRef]

39. Marques Fernandes, M.; Baeyens, B. Cation exchange and surface complexation of lead on montmorillonite and illite including competitive adsorption effects. Appl. Geochem. 2019, 100, 190-202. [CrossRef]

40. Arenas, L.T.; Lima, E.C.; Santos, A.A.D.; Vaghetti, J.C.P.; Coasta, T.M.H.; Benvenutti, E.V. Use of statistical design of experiments to evaluate the sorption capacity of 1,4-diazoniabicycle[2,2,2]octane silica chloride for Cr(VI) adsorption. Colloids Surf. A Physiochem. Eng. Asp. 2006, 297, 240-248. [CrossRef]

41. Chang, E.E.; Chiang, P.C.; Lu, P.H.; Ko, Y.W. Comparisons of metal leachability for various wastes by extraction and leaching methods. Chemosphere 2001, 45, 91-99. [CrossRef]

42. Gálvez-Martos, J.L.; Styles, D.; Schoenberger, H.; Zeschmar-Lahl, B. Construction and demolition waste best management practice in Europe. Resour. Conserv. Recycl. 2018, 136, 166-178. [CrossRef]

43. Gomes, G.M.F.; Mendes, T.F.; Wada, K. Reduction in toxicity and generation of slag in secondary lead process. J. Clean. Prod. 2011, 19, 1096-1103. [CrossRef]

44. Huggett, J.M. Reference Module in Earth Systems and Environmental Sciences. Clay Miner. 2015. [CrossRef]

45. Kreusch, M.A.; Ponte, M.J.J.S.; Ponte, H.A.; Kaminari, N.M.S.L.; Marino, C.E.B.; Mymrin, V. Techonologial improvements in automotive battery recycling. Resour. Conserv. Recycl. 2007, 52, 368-380. [CrossRef]

46. Montgomery, D.C.; Runger, G.C.; Hubele, N.F. Engineering Statistics; John Wiley \& Sons, Inc.: New York, NY, USA, 2001.

47. Ponnusami, V.; Krithika, V.; Madhuram, R.; Srivastana, S.N. Biosorption of reactive dye using acid-treated rice husk: Factorial design analysis. J. Hazard. Mater. 2007, 142, 397-403. [CrossRef]

48. Al-Qaim, F.F.; Mussa, Z.H.; Yuzir, A.; Abdullah, M.P.; Othman, M.R. Full Factorial Experimental Design for Carbamazepine Removal Using Electrochemical Process: A Case Study of Scheming the Pathway Degradation. J. Braz. Chem. Soc. 2018, 29, 1721-1731. [CrossRef]

49. Javanbakht, V.; Ghoreishi, S.M. Application of response surface methodology for optimization of lead removal from an aqueous solution by a novel superparamagnetic nanocomposite. Adsorpt. Sci. Technol. 2017, 35, 241-260. [CrossRef]

50. Yilmaz, O.; Çokça, E.; Ünlü, K. Comparison of Two Leaching Tests to Assess the Effectiveness of Cement-Based Hazardous Waste Solidification/Stabilization. Turkish J. Eng. Environ. Sci. 2003, 27, 201-212. 